\title{
FEEDING DYNAMICS AND ECOMORPHOLOGY OF Oligosarcus jenynsii (GUNTHER, 1864) AND Oligosarcus robustus (MENEZES, 1969) IN THE LAGOA FORTALEZA, SOUTHERN BRAZIL
}

\author{
NUNES, D. M. and HARTZ, S. M. \\ Programa de Pós-Graduação em Ecologia, Universidade Federal do Rio Grande do Sul, \\ Av. Bento Gonçalves, 9500, CEP 91501-970, Porto Alegre, RS, Brazil \\ Correspondence to: Sandra Maria Hartz, Programa de Pós-Graduação em Ecologia, \\ Universidade Federal do Rio Grande do Sul, Av. Bento Gonçalves, 9500, \\ CEP 91501-970, Porto Alegre, RS, Brazil, e-mail: hartzsm@ecologia.ufrgs.br
}

Received September 3, 2003 - Accepted March 16, 2004 - Distributed February 28, 2006

(With 5 figures)

\begin{abstract}
Oligosarcus jenynsii and Oligosarcus robustus are fishes of Characidae family that occur in Rio Grande do Sul, Uruguay and northern Argentina. This work purported to study the feeding dynamics (repletion and hepatosomatic indexes and condition factor) over time, and to investigate the coexistence of these two species by evaluating the partition of resources using qualitative and quantitative analyses of diet, temporal and spatial segregation throughout the water column and some ecomorphological aspects of the species in the Lagoa Fortaleza. Specimens were sampled monthly, from May 2000 to April 2001 during $24 \mathrm{~h} /$ month, using stationary gill nets of different mesh sizes. The records of each individual included total and standard length; total, stomach and liver weight; sex and stomach repletion. The variation of the mean values of repletion index and relative frequencies of stomach repletion stages indicate that $O$. jenynsii and $O$. robustus do not present seasonal differences in feeding intensity. The hepatosomatic index shows an allocation of energy to the liver during every period except reproduction, when part of the energy is used for gonad maturation. The estimated condition factor for both species reveals an increase in the reproductive period, evidencing the influence of gonads upon the condition of the fish. The diet analysis revealed that $O$. robustus is piscivorous, whereas $O$. jenynsii is a generalist carnivore, tending to piscivory as well. The active period of $O$. robustus is more concentrated at sunrise and sunset, whereas $O$. jenynsii is continually active, a characteristic related to hunting for prey. The ecomorphological analysis revealed differences between the two species in the dimensions of the mouth. Evidence suggests that the species coexist, sharing food sources, differing in oral morphology but ingesting similar prey, possibly because food is not a limiting factor in the environment.
\end{abstract}

Keywords: Characidae, Oligosarcus, feeding, ecomorphology.

\section{RESUMO}

\section{Dinâmica da alimentação e ecomorfologia de Oligosarcus jenynsii (Gunther, 1864) e Oligosarcus robustus (Menezes, 1969) na Lagoa Fortaleza, Sul do Brasil}

Oligosarcus jenynsii e Oligosarcus robustus são peixes pertencentes à família Characidae, sendo espécies ocorrentes no Rio Grande do Sul, Uruguai e norte da Argentina. Este estudo objetivou analisar os índices de repleção e hepatossomático e o fator de condição ao longo do tempo, fazer uma análise quali-quantitativa da dieta, e avaliar a segregação temporal e espacial ao longo da coluna d’água e ecomorfologia, como parâmetros de coexistência entre estas duas espécies. Os exemplares foram amostrados mensalmente, de maio de 2000 a abril de 2001, durante 24 horas/mês, com o auxílio de redes de espera de diversas malhagens. De cada indivíduo foram registradas medidas de comprimento total e padrão, peso total, peso 
do estômago e do fígado, sexo e estádio de repleção estomacal. Os resultados demonstram que $O$. jenynsii e $O$. robustus não apresentam um período alimentar definido, alimentando-se durante todo o tempo conforme a variação dos valores médios do índice de repleção, bem como das frequiências relativas dos estádios de repleção estomacal. O índice hepatossomático demonstra uma alocação de energia para o fígado durante todo o período, exceto na época reprodutiva, quando a energia é transferida para a maturação gonadal. $\mathrm{O}$ fator de condição estimado para as duas espécies revelou um aumento na época reprodutiva, evidenciando a influência das gônadas na condição em que se encontra o peixe. As análises na dieta revelaram que $O$. robustus é piscívoro, enquanto $O$. jenynsii se mostrou um carnívoro mais generalista, tendendo à piscivoria. O período de atividade das espécies foi crepuscular e está diretamente relacionado com a captura de presas. As análises ecomorfológicas revelaram diferenças no tamanho da cabeça e dimensões da boca entre as espécies. Os resultados obtidos sugerem que as espécies coexistem partilhando o recurso alimentar, diferindo em sua morfologia bucal, ingerindo, no entanto, presas similares porque o alimento pode não ser um fator limitante no ambiente.

Palavras-chave: Characidae, Oligosarcus, alimentação, ecomorfologia.

\section{INTRODUCTION}

Studies about feeding aspects include basic knowledge about the biology of species, a grasp of the trophic organization of ecosystems and quantitative knowledge about the biological mechanisms of interaction among species, such as predation and competition (Esteves \& Aranha, 1999). In this context, ecomorphology is the branch of ecology that investigates the relationships between the morphological and ecological aspects of individuals, populations, guilds and communities. Studies in this field identify the constitution of organisms and the evolutionary consequences of their final design, whose relationship can be understood based on the adaptation concept (Peres-Neto, 1999). Ecomorphological studies also serve as a tool to draw inferences about the partition of resources, defined as any substantial difference in resource exploitation among species, which may relate to diet or spatial and temporal differences in the use of habitat (Ross, 1986). Thus, communities structured upon competitive interactions should present some limitations in the similarity of resource use to ensure the coexistence of species (Peres-Neto, 1999). Although competition may occur if resources are limited, the segregations we observe today may be the consequence of exclusion or competitive "displacement" in the past. This "competitive displacement", which may be related to ecomorphological or behavioral differences among species, is genetically fixed through the speciation process.
The species Oligosarcus jenynsii (Günther, 1864) and Oligosarcus robustus (Menezes, 1969) are fishes of Characidae family whose geographic distribution coincides and overlaps in southern Brazil (Menezes, 1988). These are sympatric and abundant species in the coastal lakes of the Tramandaí River basin on the coastal plains of the state of Rio Grande do Sul. Albeit abundant species, few studies have been dedicated to them.

The feeding ecology of $O$. robustus is still unknown. The diet of Oligosarcus jenynsii was studied in a river in Argentina (Aquino, 1991), in the region of Córdoba (Haro \& Gutiérrez, 1985) and in the Lagoa Caconde, an isolated lagoon on the coastal plains of the state of Rio Grande do Sul (Hartz et al., 1996). Another report of the diet of the genus is given in Gealh \& Hahn (1998), who studied Oligosarcus longirostris in a river in the state of Paraná. These studies involved investigations into feeding time, hepatosomatic index, condition factor and diet analyses.

Given that these are abundant and sympatric species, the aim of this work is to study the feeding dynamics of $O$. jenynsii and $O$. robustus based on temporal variations of the relevant parameters (repletion and hepatosomatic indexes and condition factor), and to investigate the coexistence of these two species by evaluating their partition of resources, based on qualitative and quantitative analyses of diet, their temporal and spatial segregation throughout the water column, and some ecomorphological aspects. 


\section{MATERIAL AND METHODS}

This study was conducted at the Lagoa Fortaleza in the town of Cidreira, Rio Grande do Sul, Brazil. This lagoon is part of the TramandaíSul subsystem located between the Manuel Nunes and Cidreira lakes $\left(30^{\circ} 08^{\prime} \mathrm{S}, 50^{\circ} 13^{\prime} \mathrm{W}\right)$. This freshwater body has a surface area of $18.54 \mathrm{Km}^{2}$ and a mean depth of $1.74 \mathrm{~m}$ (Schwarzbold \& Schäfer, 1984).

The specimens were collected monthly, from May 2000 to April 2001, using three sets of stationary gill nets with mesh sizes ranging from 15 to $40 \mathrm{~mm}$ between knots, and involved a fishing effort of $24 \mathrm{~h} /$ month. The fishes were removed from the gill nets at sunrise, noon and sunset at three different stations in the lagoon. Each individual was measured (length $=\mathrm{mm}$, weight $=\mathrm{g}$ ) for total length (Lt), from the tip of the snout to the end of the caudal fin; standard length (Ls), from the tip of the snout to the insertion of the caudal fin; total weight (Wt); stomach (we) and liver (wf) weight. They were also sexed and their stomach repletion ascertained according to the quantity of food in the stomach: I (empty), II (partially full) and III (full). The full stomachs were placed in $4 \%$ formalin and preserved in $70 \%$ alcohol.

We followed the methodology proposed by Santos (1978), establishing bimonthly distributions of relative frequencies of each repletion stage and mean values of repletion (RI) and hepatosomatic (HI) indexes obtained, respectively, from the relationship between stomach and total weight and liver weight and total weight. The mean condition factor was also estimated bimonthly (total and without the gonad and stomach weight) based on the relationship of weight $v s$. length (Le Cren, 1951) of each species (Wt $=0.0205 \times \mathrm{Lt}^{3,027}$, $\mathrm{Wt}=0.0188 \times \mathrm{Lt}^{3,172}$ for males and females of O. jenynsii and $\mathrm{Wt}=0.8194 \mathrm{x} \mathrm{Lt}^{3,051}$, $\mathrm{Wt}=0.768 \times \mathrm{Lt}^{3,124}$ for males and females of O. robustus, respectively).

The validity of the use of the repletion and hepatosomatic indexes was tested using linear regressions among we, wf and $\mathrm{Wt}$, followed by analyses of variance and Tukey's test (Zar, 1996).

The food items were identified to the best possible taxonomic resolution. The material was initially analyzed according to the method of frequency of occurrence (Hyslop, 1980). A feeding importance index (FII) ranging from 0 to 1 was then established for each item according to GranadoLorencio \& Garcia-Novo (1986). This index associates the frequency of occurrence of a given item with its abundance, which is derived from a semi-quantitative scale, with the contribution of each food item estimated based on the volume it occupied in relation to the total stomach content (Hyslop, 1980). The scale was as follows: 3 - very abundant (more than $50 \%$ of the volume); 2 abundant (from $25 \%$ to $50 \%$ ); 1 - scarce (less than $25 \%$ ); and $0-$ (absent).

Following Guillen \& Granado (1984), we considered main food items those with values of FII above 0.3, additional food items those from 0.3 to 0.15 and incidental food items those with less than 0.15 . The data were grouped into two annual periods: cold months (March to August) and hot months (September to February). The degree of feeding overlap between $O$. jenynsii and $O$. robustus was calculated using Morisita's simplified index (Krebs, 1989). The similarity was considered significant when the values were above 0.6 (Zaret \& Rand, 1971). Prey size was evaluated based on the literature (Pennak, 1978), and on measurements of items whenever possible.

The period of activity was determined using the distribution of relative frequencies of individuals sampled in each of the three capture periods (sunrise, noon and sunset) and of stomachs with "full" repletion stage, analyzed by $\chi^{2}$ test (Zar, 1996).

Measurements of head length and mouth height and width were recorded for ecomorphological studies, and were transformed into ecomorphological attributes (Watson \& Balon, 1984; Hugueny \& Pouilly, 1999; Zuanon, 1999): RHL - relative head length, obtained from the division of head length by Lp; RMW - relative mouth width, obtained from the division of mouth width by Lp; RMH - relative mouth height, obtained from the division of the mouth height by Lp; MCR - mouth configuration rate, obtained from the division of the mouth height by its width; high values indicate fishes with narrow mouths (Zuanon, 1999).

The MULTIV software (Pillar, 1997) was used for multivariate analyses; a principal component analysis was done starting from a matrix of correlations among the variables (ecomorphological attributes) using 20 sampling 
unities: 10 individuals of each species, all adults, to minimize possible allometry along the ontogenetic development. On interpreting the importance of the ecomorphological attributes in the distribution of species along the axis, the variables with correlation values equal to or higher than 0.60 were considered significant (Hugueny \& Pouilly, 1999; Zuanon, 1999).

\section{RESULTS}

A total of 143 individuals of Oligosarcus jenynsii and 405 individuals of Oligosarcus robustus were captured, with a predominance of females (Table 1).

The results of the linear regressions of stomach, liver and total weight are shown in Table 2. Since there was a linear regression (linear coefficient $=0$ ) between stomach and liver weight in relation to total weight, the feeding activity was assessed using the repletion index followed by the hepatosomatic index, which enables one to find an indication of the period of higher energy storage.

The mean values of repletion index (RI) showed differences in the feeding period between male and female only for $O$. jenynsii (Fig. 1). For this species, males presented higher values of RI in Jan/Feb, whereas females presented very similar values of RI throughout the year, with no distinct feeding period. The same was found for both sexes of $O$. robustus, which fed throughout the sampling period (Fig. 1). However, the analysis of variance revealed significant differences among the bimonthly mean values of the repletion index for male and female Oligosarcus jenynsii, $\left(\mathrm{F}_{\text {calc }}=8.86\right.$ $\mathrm{P}<0.001$ and $3.42 \mathrm{P}=0.007$, respectively). Tukey's analysis revealed significant differences between
$\mathrm{Jan} / \mathrm{Feb}$ and the other bimonthly periods for males of $O$. jenynsii, indicating this is a period of higher feeding activity. $O$. jenynsii females presented significant differences between the periods before (Mar/Apr) and after (Jul/Aug) the reproductive pe$\operatorname{riod}$ (per.obs.) and the period when gonad maturation begins (May/Jun). The analysis of variance of the bimonthly mean values of repletion index also revealed significant differences for O. robustus males and females $\left(\mathrm{F}_{\text {calc }}=4.89 \mathrm{P}<0.001\right.$ and 2.85 $\mathrm{P}=0.016$, respectively). Tukey's test evidenced a difference between the period when reproduction begins (May/Jun) and the period of peak of gonad maturation for both sexes of $O$. robustus.

The bimonthly variation of mean values of hepatosomatic index for $O$. jenynsii and $O$. robustus males and females (Fig. 1) followed the repletion index along general lines. In May/Jun, when gonad maturation begins and part of the energy is converted into production and maturation of gametes, the values of hepatosomatic index were lower in both species. The highest values of $\mathrm{HI}$ in $O$. jenynsii occurred in Mar/Apr for females and Nov/Dec for males. On the other hand, the highest values of HI in O. robustus were recorded in Jul/Aug and the trend for bimonthly variations of HI seemed to be well synchronized in males and females, whereas this trend between males and females was different in $O$. jenynsii.

The analysis of variance did not reveal significant differences in the mean values of hepatosomatic index for Oligosarcus jenynsii males, but females presented statistical differences $\left(\mathrm{F}_{\text {calc }}=2.199 \mathrm{P}=0.071\right.$ and $59.136 \mathrm{P}<0.001$, respectively). Tukey's analysis revealed significant differences for $O$. jenynsii females between the

TABLE 1

Number of individuals of $O$. jenynsii and $O$. robustus captured from May 2000 to April 2001 in the Lagoa Fortaleza, RS, Brazil, and their total length variation (Lt).

\begin{tabular}{|l|l|c|c|}
\hline \multicolumn{1}{|c|}{ Species } & & N & Variation of Lt (mm) \\
\hline \multirow{3}{*}{ Oligosarcus jenynsii } & Males & 51 & $113-210$ \\
\cline { 2 - 4 } & Females & 92 & $115-243$ \\
\cline { 2 - 4 } & Total & 143 & - \\
\hline \multirow{3}{*}{ Oligosarcus robustus } & Males & 193 & $121-242$ \\
\cline { 2 - 4 } & Females & 212 & $124-297$ \\
\cline { 2 - 4 } & Total & 405 & - \\
\hline
\end{tabular}


TABLE 2

Linear regressions of stomach weight and total weight (Wt) for each repletion stage and linear regression of liver weight (wf) and total weight (Wt) of Oligosarcus jenynsii and Oligosarcus robustus captured in the Lagoa Fortaleza from May 2000 to April 2001.

\begin{tabular}{|c|c|c|c|c|c|c|}
\hline \multicolumn{4}{|c|}{ Oligosarcus jenynsii } & \multicolumn{3}{|c|}{ Oligosarcus robustus } \\
\hline Stages & b & $\mathbf{r}$ & $\mathbf{N}$ & b & $\mathbf{r}$ & $\mathbf{N}$ \\
\hline \multicolumn{7}{|l|}{ Males } \\
\hline I & 0.0116 & 0.84 & 38 & 0.0096 & 0.79 & 122 \\
\hline II & 0.018 & 0.84 & 9 & 0.0184 & 0.72 & 54 \\
\hline III & 0.0313 & 0.95 & 4 & 0.0483 & 0.83 & 17 \\
\hline (wfxWt) & 0.0071 & 0.78 & 51 & 0.0068 & 0.77 & 193 \\
\hline \multicolumn{7}{|l|}{ Females } \\
\hline I & 0.0115 & 0.83 & 59 & 0.0106 & 0.78 & 126 \\
\hline II & 0.0216 & 0.86 & 17 & 0.0204 & 0.78 & 54 \\
\hline III & 0.089 & 0.77 & 16 & 0.0587 & 0.78 & 32 \\
\hline (wfxWt) & 0.0079 & 0.77 & 92 & 0.008 & 0.76 & 212 \\
\hline
\end{tabular}

$\mathrm{b}=$ regression coefficient; $\mathrm{r}=$ linear correlation coefficient $(\alpha=0.05) ; \mathrm{N}=$ number of individuals; $\mathrm{I}=$ empty; $\mathrm{II}=$ partially full; and III = full.

Oligosarcus jenynsii
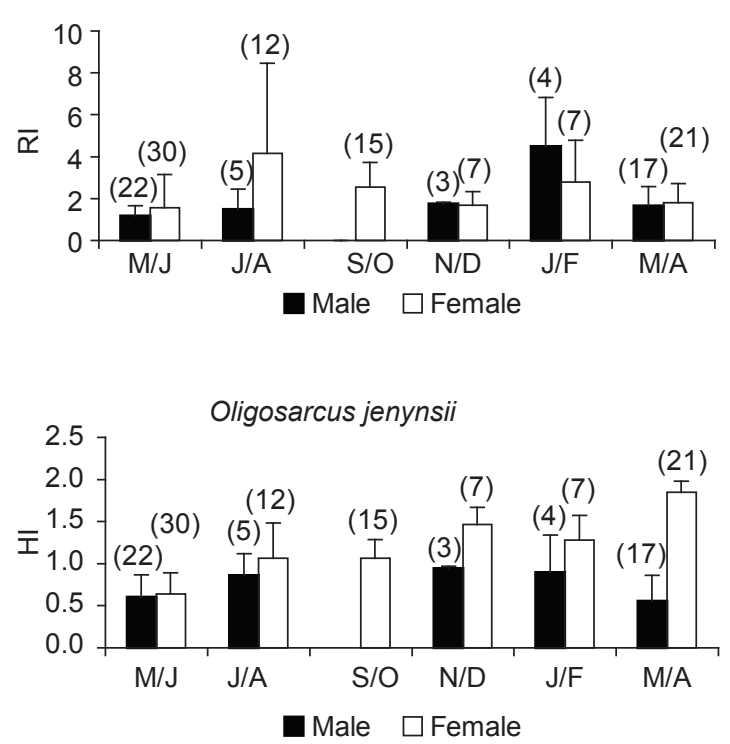

Oligosarcus robustus

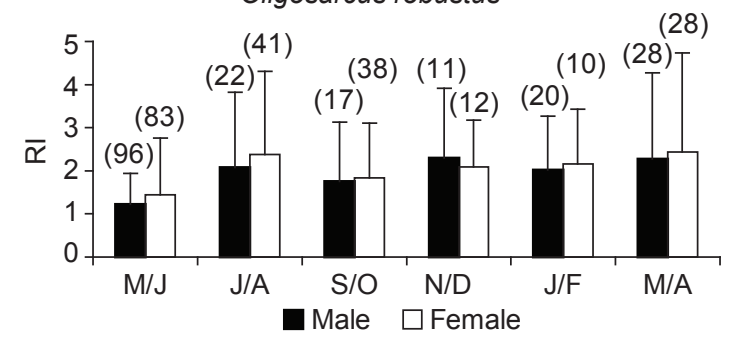

Oligosarcus robustus

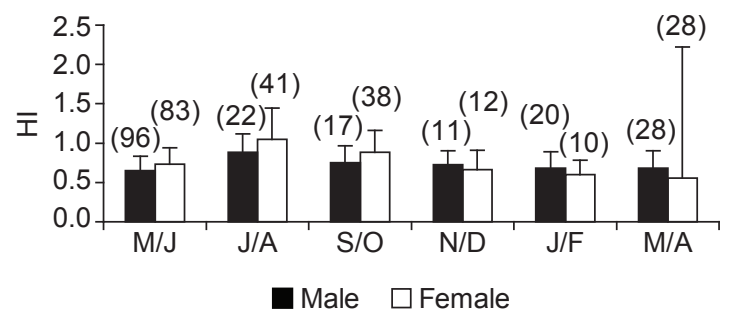

Fig. 1 - Bimonthly variation of mean values of repletion index (RI) and hepatosomatic index (HI) in Oligosarcus jenynsii and Oligosarcus robustus males and females captured in the Lagoa Fortaleza from May 2000 to April 2001. The vertical bars correspond to the standard deviation and the number above the bars indicates the total individuals captured in each period. No O. jenynsii male was captured in Sep/Oct.

first bimonthly period in which reproduction begins (May/Jun) and the subsequent periods. The analysis of variance of the mean values of hepatosomatic index of $O$. robustus revealed significant differences between males and females
$\left(\mathrm{F}_{\text {calc }}=5.371 \mathrm{P}<0.001\right.$ and $2.509 \mathrm{P}=0.031$, respectively). Tukey's test evidenced differences for males and females between the bimonthly period in which reproduction begins (May/Jun) and the subsequent periods. 
The distribution of relative frequencies of repletion stages (Fig. 2) corroborates the variation in the repletion index, revealing the existence of full or partially full stomachs throughout the sampling period. A frequency of about $50 \%$ of empty stomachs was found in all the study periods in both sexes of both species, with the highest values falling in the bimonthly period when reproduction begins (May/Jun).

The mean values of the condition factor (cf) and cf without the gonads weight (cf-wg) and without the stomach weight (cf-we) (Fig. 3) increased in Nov/Dec for males and in Jul/Aug for females of $O$. jenynsii and in Jul/Aug for males and females of $O$. robustus. The greatest differences in the mean values of the condition factor without the gonads and stomach weight were observed in Jul/ Aug only for females of both species.

Stomachs in a full repletion stage were analyzed from 22 specimens of Oligosarcus jenynsiii, whose total length ranged from 113 to $243 \mathrm{~mm}$, and 66 specimens of Oligosarcus robustus with lengths ranging from 127 to $271 \mathrm{~mm}$. The food items ingested by $O$. jenynsii and $O$. robustus as well as the feeding importance index (FII) are presented separately (Table 3) for the hot (September to February) and cold (March to August) seasons. Oligosarcus jenynsii was found to be a generalist carnivore tending to piscivory, whereas $O$. robustus proved to be a typical piscivorous fish.

The diet of Oligosarcus jenynsii was more diversified, including Characiform fishes and Decapoda invertebrates as main food items, Coleoptera as an additional food item and other invertebrates as occasional food items; sand was found in some stomachs. Oligosarcus robustus presented fishes of the orders of Characiformes, Clupeiformes and Siluriformes as main food items; other items were found only as occasional food items. The genera that could be identified were Astyanax, Hyphessobrycon and Lycengraulis. The measurements of prey and data reported in the literature revealed that fish food items were larger than $40 \mathrm{~mm}$ and invertebrates smaller than $40 \mathrm{~mm}$; invertebrates of the order Decapoda did not exceed $30 \mathrm{~mm}$ in total length. The feeding overlap, calculated in pairs between the hot and cold seasons for both species, showed a high similarity in the
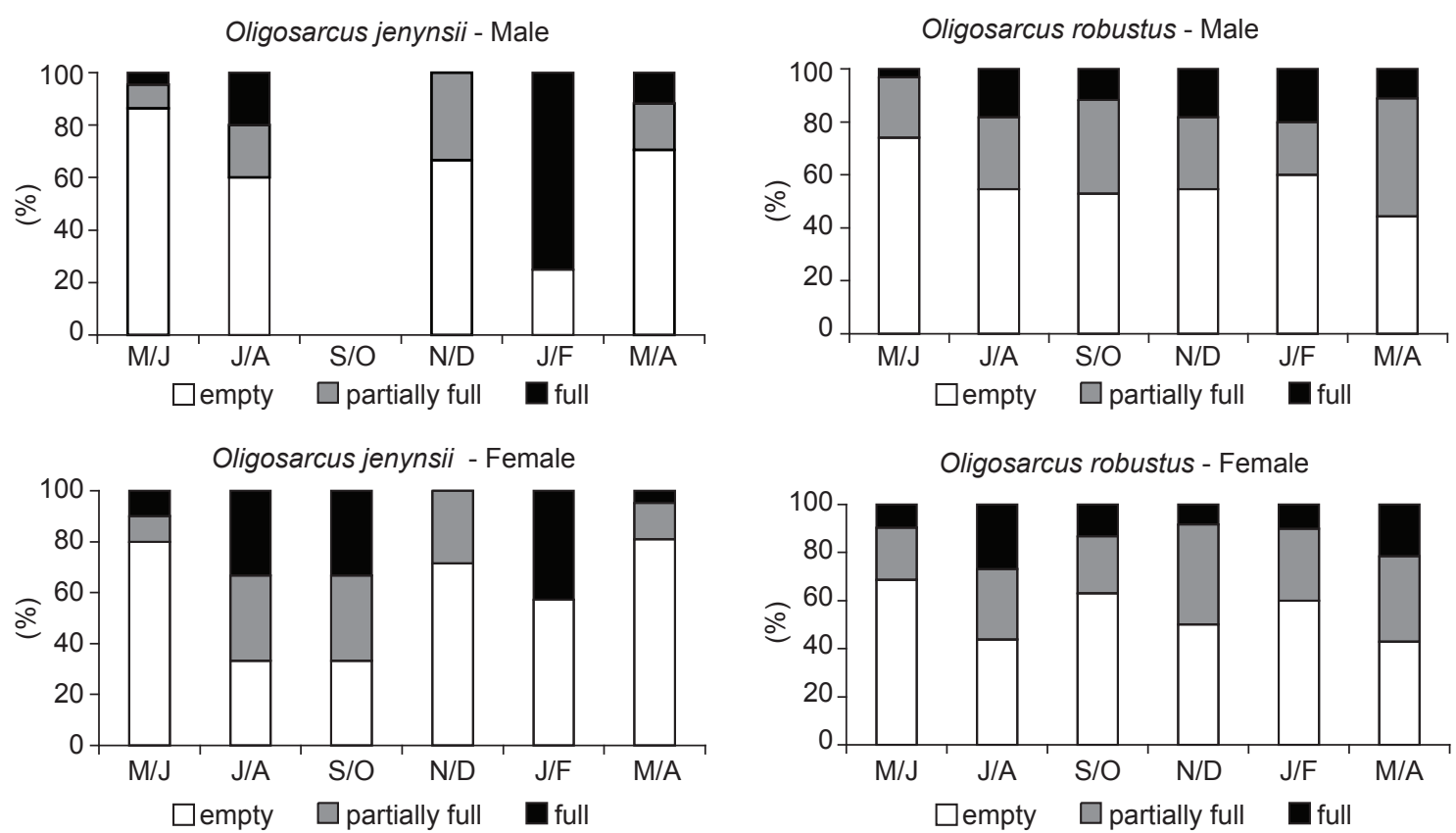

Fig. 2 - Bimonthly distribution of relative frequencies of stomach repletion stages of Oligosarcus jenynsii and Oligosarcus robustus males and females captured in the Lagoa Fortaleza from May 2000 to April 2001. No O. jenynsii male was captured in Sep/Oct. 

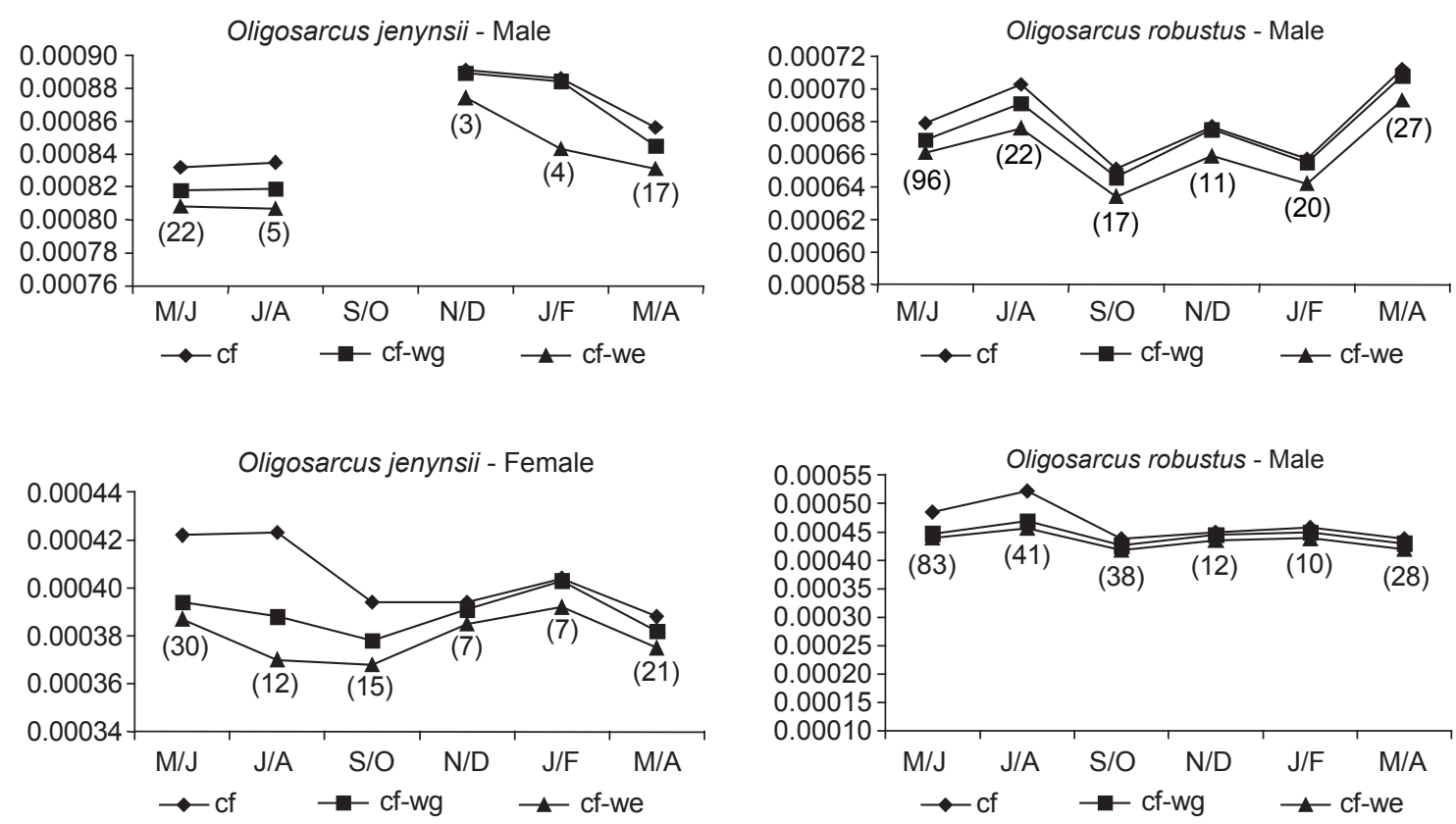

Fig. 3 - Bimonthly variation of mean values of condition factor (cf), condition factor without the gonad weight (cf-wg) and without the stomach weight (cf-we) of Oligosarcus jenynsii and Oligosarcus robustus males and females captured in the Lagoa Fortaleza from May 2000 to April 2001. No O. jenynsii male was captured in Sep/Oct.

TABLE 3

Values of frequency of ocurrence (fr) and feeding importance index (FII) of items ingested by Oligosarcus jenynsii and O. robustus in the Lagoa Fortaleza from May 2000 to April 2001 (food items considered as main and additional are in bold). Cold = March to August; and Hot $=$ September to February.

\begin{tabular}{|c|c|c|c|c|c|c|c|c|c|}
\hline \multirow{2}{*}{\multicolumn{2}{|c|}{ Item }} & \multicolumn{8}{|c|}{ Species } \\
\hline & & \multicolumn{4}{|c|}{ Oligosarcus jenynsii } & \multicolumn{4}{|c|}{ Oligosarcus robustus } \\
\hline & & \multicolumn{2}{|c|}{ Cold } & \multicolumn{2}{|c|}{ Hot } & \multicolumn{2}{|c|}{ Cold } & \multicolumn{2}{|c|}{ Hot } \\
\hline & & fr & FII & fr & FII & fr & FII & fr & FII \\
\hline Diptera & Larva & 0 & 0 & 0.083 & 0.027 & 0 & 0 & 0 & 0 \\
\hline Efemeroptera & Adult & 0 & 0 & 0 & 0 & 0.021 & 0.007 & 0 & 0 \\
\hline \multirow[t]{2}{*}{ Odonata } & Nymph & 0 & 0 & 0.083 & 0.055 & 0 & 0 & 0 & 0 \\
\hline & Adult & 0.09 & 0.03 & 0.166 & 0.083 & 0 & 0 & 0.1 & 0.06 \\
\hline \multirow[t]{2}{*}{ Coleoptera } & Larva & 0.09 & 0.03 & 0.166 & 0.166 & 0 & 0 & 0 & 0 \\
\hline & adult & 0 & 0 & 0.25 & 0.25 & 0.021 & 0.021 & 0.1 & 0.1 \\
\hline Insecta n.i. & - & 0.18 & 0.09 & 0.083 & 0.027 & 0 & 0 & 0.1 & 0.1 \\
\hline Amphipoda & - & 0.09 & 0.03 & 0.083 & 0.055 & 0 & 0 & 0 & 0 \\
\hline Decapoda & - & 0.181 & 0.181 & 0.747 & 0.249 & 0.043 & 0.043 & 0.15 & 0.08 \\
\hline Gastropoda & - & 0.09 & 0.09 & 0 & 0 & 0 & 0 & 0 & 0 \\
\hline Fish & - & 0.636 & 0.636 & 0.416 & 0.388 & 0.869 & 0.869 & 0.8 & 0.766 \\
\hline Sand & - & 0 & 0 & 0.083 & 0.083 & 0 & 0 & 0 & 0 \\
\hline Stomach analysed & - & 11 & - & 12 & - & 46 & - & 20 & - \\
\hline Total length (mm) & - & 1113-243 & - & $138-217$ & - & $127-271$ & - & $127-266$ & - \\
\hline
\end{tabular}

Diptera $=$ Chironomidae larvae; fish $=$ Characiformes, Clupeiformes and Siluriformes orders. 
diet between the species and among the sampling periods (Table 4). The lowest values of overlapping between the species were found during the cold and hot periods and the diet of $O$. jenynsii was more distinct between the seasonal periods.

The distribution of frequencies of full stomachs and of individuals along the day revealed little activity at noon for both species (Fig. 4). Otherwise, Chi-square tests revealed significant differences of frequency of individuals and of full stomachs $\left(\chi^{2}=79.70\right.$ and 10.36 respectively, $\mathrm{df}=3$ $\mathrm{P}<0.005)$ among the sampling times only for Oligosarcus robustus. Oligosarcus jenynsii showed no statistical differences among the sampling times in terms of frequency of individuals and full stomachs $\left(\chi^{2}=5.08\right.$ and 3.0 respectively, $\mathrm{df}=3$ $\mathrm{P}<0.005)$.

The two first axes of the principal components analysis explained $85.07 \%$ of the total variance found (Table 5). The mouth configuration rate and the relative head length were the ecomorphological attributes that added positive and significant values to the formation of the first component; the relative mouth width added a negative value. Although these variables presented the highest correlation values on the axis, they did not clearly separate the species on the graph (Fig. 5). For the second component, the contribution of the relative mouth height was negative and significant (Table 5). High values of relative mouth height indicate the ingestion of large items, separating $O$. robustus from $O$. jenynsii on axis 2 .

\section{DISCUSSION}

The results of repletion index found for both species were similar to those presented by Hartz et al. (1996) for O. jenynsii from the Lagoa Caconde, where the highest frequency of empty stomachs was directly related to the species' reproduction. This may possibly be due to the need for a larger available space in the abdominal cavity to accommodate the increased size of the gonads with oocyte maturation, mainly in females. Gealh (1996) recorded the feeding period of Oligosarcus longirostris in the Salto

TABLE 4

Values of feeding overlap index between Oligosarcus jenynsii and $O$. robustus captured in Fortaleza Lake from May 2000 to April 2001. Cold = March to August; and Hot = September to February.

\begin{tabular}{|l|l|l|l|c|}
\hline Sp/period & $O j$ Cold & $O j$ Hot & Or Cold & $O$ Hot \\
\hline$O j$ Cold & 1 & - & - & - \\
\hline$O j$ Hot & 0.777 & 1 & - & - \\
\hline Or Cold & 0.923 & 0.653 & 1 & - \\
\hline Or Hot & 0.955 & 0.743 & 0.976 & 1 \\
\hline
\end{tabular}

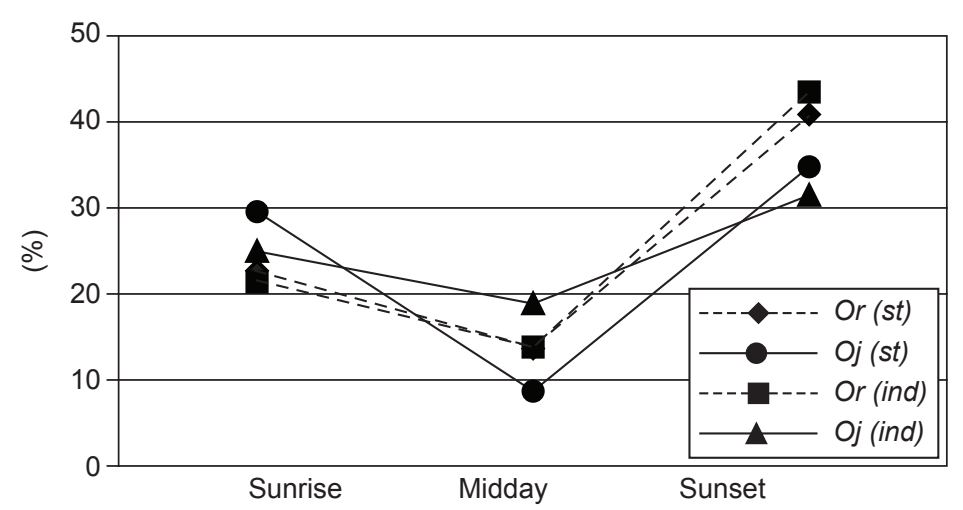

Fig. 4 - Distribution of frequencies of individuals (ind.) and full stomachs (st) of Oligosarcus jenynsii and Oligosarcus robustus captured at sunrise, noon and sunset in the Lagoa Fortaleza from May 2000 to April 2001. 


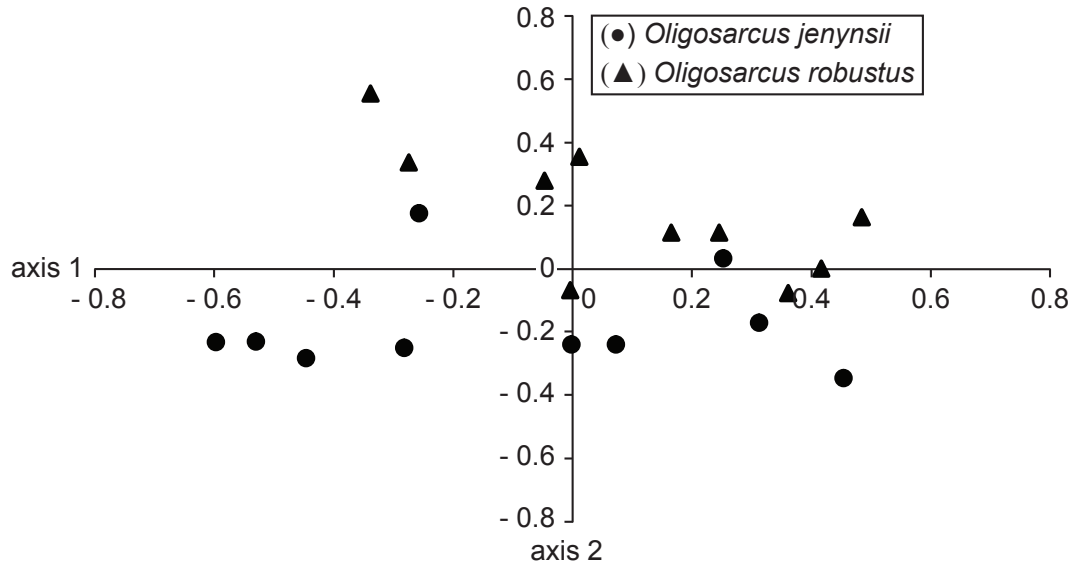

Fig. 5 - Graphic projection of principal components generated by the analysis of four ecomorphological attributes of Oligosarcus jenynsii $(\bullet)$ and Oligosarcus robustus $(\boldsymbol{\Delta})$ captured in the Lagoa Fortaleza from May 2000 to April 2001.

TABLE 5

Correlation values of four ecomorphological attributes on the two first axes of the principal component analysis for Oligosarcus jenynsii and $O$. robustus of Fortaleza Lake (values in bold were considered significant for the total variance explained by the components).

\begin{tabular}{|l|c|c|}
\hline Atributes & PC 1 & PC 2 \\
\hline RHL & $\mathbf{0 . 7 0 3 4 6}$ & 0.30073 \\
\hline RMW & $\mathbf{- 0 . 7 6 3 3 2}$ & -0.54342 \\
\hline RMH & 0.45554 & $\mathbf{- 0 . 8 8 7 2 4}$ \\
\hline MCR & $\mathbf{0 . 9 4 3 2 3}$ & -0.23555 \\
\hline Autovalues & 2.17 & 1.22 \\
\hline Variance (\%) & 54.368 & 30.71 \\
\hline
\end{tabular}

Segredo reservoir, state of Paraná, in the months of spring (September, October and November), which coincided with greater abundance of prey in the environment and was inversely related to the reproduction period. Although the results of the analysis of variance revealed significant differences among the bimonthly periods in the mean values of repletion index, evidencing an inverse relation to the reproductive period, our study showed no definite feeding period for either of the species. The species presented stomachs with full and partially full repletion stages throughout the sampling year, even during the reproductive season. Barbieri et al. (1982) observed continuous feeding during the reproductive period of Hoplias malabaricus, which is also a piscivorous species, suggesting a pattern of absence of seasonality of gonadosomatic index and repletion index for fishes of this trophic level.

For some $O$. jenynsii males, the feeding period may be related to differences in resource abundance, activity period between the sexes, and the ingestion of many food items. The low frequencies of full or partially full stomachs and the high frequency of empty stomachs recorded for both species may be directly related to the physiology of carnivores with a tendency for piscivory (Loureiro \& Hahn, 1996). According to Zavala-Camin (1996), satiation in carnivores, i.e., a decrease or complete loss of appetite after satisfactory ingestion of food, takes from one to three hours. The digestion rate of food from animal sources is very high and makes the individual feed continuously. 
The mean values of hepatosomatic index revealed allocation of energy to the liver throughout the period except for the initial reproduction peak, when more energy is directed to the production and maturation of gametes than to somatic growth. This is expected to apply mainly to females, whose gonads are generally larger and heavier and yolk is a highly energetic material, which means its production requires more energy. Thus, the decrease in the values of $\mathrm{HI}$ for some species is relatively coincident with the period of gonad development, when yolk is produced. In our study, this relation was better observed in females than in males of Oligosarcus jenynsii. In contrast, we could identify the differences of $\mathrm{HI}$ for both sexes of $O$. robustus. Possibly our findings for Oligosarcus jenynsii were not so clear due to the few male specimens. Also, the magnitude of bimonthly variation in HI for Oligosarcus jenynsii males and females was not as constant as for $O$. robustus. This was probably due to the consumption of different kinds of prey, which causes digestion to occur under different nutrient assimilation rates; however, this was not the case for $O$. robustus, which feeds essentially on fish.

The condition factor varies as a function of several biological events such as amount of fat, susceptibility to environmental changes, gonad development and degree of parasitism (Barbieri et al., 1985). The bimonthly variation of the total condition factor found for $O$. jenynsii in this study was similar to the results found by Hartz et al. (1996). The increases corresponded to the beginning of the reproductive period for $O$. robustus and $O$. jenynsii; the latter also showed an increase in Nov/Dec for males, which may be related to abundant availability of prey. The increase in this parameter is a good indicator of reproductive activity, albeit more so for $O$. jenynsii than for $O$. robustus, and occurs in other species of the order of Characiformes (Hartz \& Barbieri, 1993). The greater difference between the mean values of the condition factor with and without the gonads weight for $O$. jenynsii possibly indicates a greater production of oocytes for this species than $O$. robustus.

The diet of $O$. jenynsii in the Lagoa Fortaleza was the same as that found by Hartz et al. (1996) and Gealh \& Hahn (1998), who also observed more generalist carnivorous habits tending toward piscivory. The variation in the FII values of additional items, e.g., invertebrates, may be directly related to the item's abundance in a particular environment. Oligosarcus robustus was found to be an essentially piscivorous specialist. The fish genera found in the diet, Astyanax, Hyphessobrycon and Lycengraulis, are abundant in the Lagoa Fortaleza and Astyanax is often found close to O. robustus (Schifino, 2002). In comparisons of adults and juveniles, most of the studies on the diet of this genus show a division. However, in our study, the absence of adequate samples of full stomachs of juveniles precluded the identification of such a division. In order to accurately identify the partition of resources, it would be interesting to ascertain whether the diet of juveniles of these two species displays high overlapping and modifications throughout their growth. It is worth noting that neither cannibalism nor predation of one species by the other was recorded in this study.

The feeding overlap between the species and sampling periods was high. Thus, evidence of their coexistence also seems to be related to abundant availability of prey. Since concurrence of these species is common in other water bodies, it is possible that their position in the same trophic group does not strongly affect their coexistence. Abundant availability of prey is a possible explanation, but spatial and temporal segregation, food size and location are also possibilities. Perhaps $O$. robustus, being more piscivorous, is more efficient than $O$. jenynsii, which tends to feed on other items. Therefore, $O$. jenynsii occupies a wider trophic niche than $O$. robustus.

The period of highest activity of $O$. robustus was similar to what Gealh (1996) found for O. longirostris in the state of Paraná. This period of activity was directly related to the capture of prey. In contrast, $O$. jenynsii did not present a statistically definite period of activity, although higher frequencies of individuals were captured at sunrise and sunset and individuals with empty stomachs at noon. Therefore, $O$. robustus seems to be a specialist predator in terms of diet and feeding time, whereas $O$. jenynsii seems to be a generalist predator. This could be a mechanism to facilitate the coexistence of the two species notwithstanding the diet overlap. Oligosarcus jenynsii possibly compensates for its lower feeding specificity by broadening the scope of its prey and period of activity. 
The records of sand and some benthic groups, such as shrimps, in the stomachs of $O$. jenynsii provide a clue about the position of this species in the water column. $O$. jenynsii may feed closer to the bottom than $O$. robustus, which feeds more on nekton, i.e., organisms that live along the water column.

The ecomorphological analyses indicated that despite their morphological similarities, these species' diet parameters differ somewhat. The relative head length, which is directly related to the size of food items, the mouth configuration rate, with high values indicating fishes with narrow mouths, and the relative mouth width, with high values indicating capacity to feed on large items (Watson \& Balon, 1984), are ecomorphological attributes that, though contributing with significant correlation values to axis 1 , did not clearly separate the species. The morphological separation was clear on axis 2 through the relative mouth height, whose high values indicate the ingestion of large items. This variable presented a higher correlation value than the relative mouth width. Oligosarcus jenynsii exhibited the highest values of this variable (negative correlation with the axis), indicating it feeds on smaller and larger items and corroborates the data on diet that include factors such as additional food items, with a more diversified diet than $O$. robustus. Alternatively, the essentially piscivorous $O$. robustus presented the lowest values of relative mouth height, despite feeding preferably on fish. This result is not so clear with the diet of the species, because $O$. robustus feeds more on large items than does $O$. jenynsii. This fact may be a result of the predation capacity of $O$. robustus, even though $O$. jenynsii presented a higher capacity for ingesting large food items.

The investigations of the Oligosarcus species in the Lagoa Fortaleza provided evidence of the partition of resources. It is not clear whether the adaptations that this genus underwent over time were the result of past competition or allopatric speciation. There is no information about what led to the differentiation of these two species or about the speciation mechanism. They may have speciated through vicariance and only later have developed geographical and habitat overlapping. Moreover, they may have speciated sympatrically by mechanisms unrelated to diet. Be that as it may, the species now live in sympatry and, in the Lagoa
Fortaleza, they segregate ecologically due to distinct periods of activity, mouth morphology and hence, prey size. Besides, there seems to be an abundance of resources that make this sympatry possible, since their diets are qualitatively very similar. It would be highly relevant and enlightening to continue this study through monitoring experiments in the laboratory to allow for a more in-depth behavioral analysis of these species. Such experiments would be necessary, since other methodologies of underwater observation require high water transparency, which is not common in the coastal water bodies of Rio Grande do Sul.

Acknowledgments - The authors gratefully acknowledge FAPERGS for funding Project $\mathrm{n}^{\circ}$ 00/0840-1, CAPES for conceding the grants for these studies, and the CENTRO DE ECOLOGIA/UFRGS and CECLIMAR/UFRGS for their logistic help. We are also indebted Drs. Fernando G. Becker, Nelson Fontoura, Willi Bruschi Jr and Geraldo Barbieri for their critical comments and suggestions, and to Mateus Pellanda for his assistance in the field and laboratory work.

\section{REFERENCES}

AQUINO, A. E., 1991, Alimentacion de Oligosarcus jenynsii (Gunther, 1864) (Osteichthyes, Characidae) em el embalse el cadillal (Tucuman, Argentina). Biologia Acuática, 15(2): 178-179.

BARBIERI, G., VERANI, J. R. \& BARBIERI, M. C., 1982, Dinâmica quantitativa da nutrição de Hoplias malabaricus (Bloch, 1794) na represa do Lobo (Brotas-Itirapina-SP) (Pisces, Erythrinidae). Rev. Brasil. Biol., 42(2): 295-302.

BARBIERI, G., VERANI, J. R., PEREIRA, J. A., BARBIERI, M. C., PERET, A. C. \& MARINS, M. A., 1985, Curva de maturação e fator de condição de Apareiodon affinis (Steindachner, 1879), A. ibitensis (Campos, 1944) e Parodon tortuosos (Eigenmann \& Norris, 1900) do rio Passa Cinco, Ipeúna-SP, (Cypriniformes, Paradontidae). Ciênc. Cult., 37(7): 1178-1183.

ESTEVES, K. E. \& ARANHA, J. M. R., 1999, Ecologia trófica de peixes de riachos, pp. 157-182. In: E. P. Caramaschi, R. Mazzoni \& P. R. Peres-Neto (eds.), Ecologia de Peixes de Riachos, Série Oecologia Brasiliensis, VI vol., PPGGEUFRJ, Rio de Janeiro, Brasil.

GEALH, A. M., 1996, Distribuição, reprodução e alimentação de Oligosarcus longirostris (Menezes \& Gery, 1983) (Osteichthyes, Characidae, Acestrorhynchinae) do Reservatório de Salto segredo-PR. Tese de Doutorado, Programa de Pós-Graduação em Ecologia e Recursos Naturais, UFSCar, São Carlos, 110p.

GEALH, A. M. \& HAHN, N. S., 1998, Alimentação de Oligosarcus longirostris Menezes \& Gery (Osteichthyes, Acestrorhynchinae) do Reservatório de Salto Segredo, Paraná, Brasil. Rev. Brasil. Zool., 15(4): 985-993. 
GRANADO-LORENCIO, C. \& GARCIA-NOVO, F., 1986, Feeding habits of the fish community in a eutrophic reservoir in Spain. Ekologia Polska, 34(1): 95-110.

GUILLEN, E. \& GRANADO, C., 1984, Alimentación de la ictiofauna del embalse de Torrejon (rio Tajo, Caceres). Limnética, 1(1): 304-310.

HARO, J. G. \& GUTIÉRREZ, M., 1985, Alimentación de Oligosarcus jenynsii (Günther, 1864) (pises, Characidae) en el Lago San Roque (Cordoba, Argentina). Rev. Assoc. Cienc. Nat. Del Litoral, 16(2): 227-235.

HARTZ, S. M. \& BARBIERI, G., 1993, Dinâmica quantitativa da alimentação de Cyphocharax voga (Hensel, 1869) da Lagoa Emboaba, RS, Brasil (Characiformes, Curimatidae). Comum. Mus. Ciênc. PUCRS, sér. Zool., 6(1): 63-74.

HARTZ, S. M., MARTINS, A. \& BARBIERI, G., 1996, Dinâmica da alimentação e dieta de Oligosarcus jenynsii (Gunther, 1864) na Lagoa Caconde, Rio Grande do Sul, Brasil (Teleostei, Characidae). B. Inst. Pesca, 23: 21-29.

HUGUENY, B. \& POUILLY, M., 1999, Morphological correlates of diet in an assemblage of West African freshwater fishes. J. Fish Biol., 54(3): 1310-1323.

HYSLOP, E. J., 1980, Stomach contents analysis - a review of methods and their application. J. Fish Biol., 17(2): 411429.

KREBS, C. J., 1989, Ecological methodology. Harper \& Row (eds), New York, 654p.

LE CREN, E. D., 1951, The length-weight, relationship and seasonal cycle in gonad weight and condition in the perch (Perca fluviatilis). J. Animal Ecol., 20(2): 201-219.

LOUREIRO, V. E. \& HAHN, N. S., 1996, Dieta e atividade alimentar da traíra, Hoplias malabaricus (Bloch, 1794) (Osteichthyes, Erythrinidae), nos primeiros anos de formação do reservatório de segredo, PR. Acta Limnológica Brasiliensia, 8(1): 195-205.

MENEZES, N. A., 1988, Implications of the distribution patterns of the species of Oligosarcus (Teleostei, Characidae) from Central and Southern South America, pp. 295-304. In: P. E. Vanzolini \& W. Ronald Heyer, (eds.), Proceedings of a
Workshop on Neotropical Distribution Patterns, Held 1216 January 1987, Academia Brasileira de Ciências, Rio de Janeiro, 488p.

PENNAK, R. W., 1978, Fresh-Water Invertebrates of the United States. John Wiley \& Sons. (eds.), New York, 803p.

PERES-NETO, P. R., 1999, Alguns métodos e estudos em ecomorfologia de peixes de riachos, pp. 209-236. In: E. P. Caramaschi, R. Mazzoni \& P. R. Peres-Neto (eds.), Ecologia de Peixes de Riachos, Série Oecologia Brasiliensis, VI vol., PPGGE-UFRJ, Rio de Janeiro, Brasil.

PILLAR, V. D. P., 1997, Multivariate exploratory analysis and randomization testing with multiv. Coenoses, 12(2-3): 145148.

ROSS, S. T., 1986, Resource partitioning in fish assemblages: a review of fiel studies. Copeia, 2(1): 352-388.

SANTOS, E. P., 1978, Dinâmica de populações aplicada à pesca e piscicultura. HUCITEC-EDUSP, São Paulo, 129p.

SCHIFINO, L. C., 2002, Estudo da comunidade íctica da Lagoa da Fortaleza, Cidreira, Rio Grande do Sul, Brasil. Tese de Doutorado, Universidade Federal de São Carlos, São Carlos, 131p.

SCHWARZBOLD, A. \& SCHÄFER, A., 1984, Gênese e morfologia das Lagoas Costeiras do Rio Grande do SulBrasil. Amazoniana, 9(1): 87-104.

ZAR, J. H., 1996, Biostatistical analysis. London, Prentice-Hall ( $2^{\mathrm{a}}$ eds), 718p.

ZARET, T. M. \& RAND, A. S., 1971, Competition in tropical stream fishes: support for the competitive exclusion principle. Ecology, 52(2): 336-342.

ZAVALA-CAMIN, L. A., 1996, Introdução aos estudos sobre alimentação natural em peixes. EDUEM, Maringá, 129p.

ZUANON, J. S., 1999, História Natural da Ictiofauna de corredeiras do Rio Xingu, na Região de Altamira, Pará. Tese de Doutorado, Universidade Estadual de Campinas, São Paulo, 214p.

WATSON, D. J. \& BALON, E. K., 1984, Ecomorphological analysis of fish taxocenoses in rainforest streams of northern Borneo. J. Fish Biol., 145(1): 303-320. 